\title{
0 pensamento democrático como princípio estruturador na vida dos povos europeus
}

\author{
Gerhard Leibholz \\ Professor da Universidade de Göttingen - Ministro \\ da Côrte Constitucional de Karlsruhe.
}

\section{$I$}

As fôrças espirituais que formaram a Europa e a consciência da unidade européia - sobretudo o Cristianismo e o classicismo humanista - determinaram também, na sua essência, o pensamento democrático tradicional do Ocidente. Não foi portanto, um acaso que, por exemplo, nos tempos de Cromwell, a democracia se tivesse definido como a religious and moral principle e the translation into non-theological language of the priesthood of all believers, e que os puritanos dos Estados Unidos houvessem colocado seus Covenants sob a soberania de Deus, também no domínio político.

Todavia, o pensamento democrático concretizou-se em formas seculares à medida que desenvolveu, nos últimos dois séculos, o seu poderio político. Neste sentido, é sintomático o fato de haverem as constituições escritas, desde a Revolução francesa, renunciado à invocação de Deus. Sòmente na Inglaterra, que não possui uma constituição escrita, conservou-se a igreja anglicana como instituição estadual e a coroa pôde manter a sua legitimidade religiosa original. Exceto isso, foram secularizados na esfera política os conceitos inicialmente religiosos: haja vista a soberania de Deus, substituída pela soberania do povo, ou o axioma da igualdade de todos perante Deus, o qual foi 
substituído pela igualdade de todos perante a lei, isto é, por um ato da vontade humana.

Mas também no pensamento democrático ocidental secularizado a tradição cristã foi um elemento atuante. Foi ela que formou o fundo para a imagem classicista humanista do mundo: a Renascença, o Iluminismo e o Direito Natural. $\leftleftarrows$ errado pensar que a nova imagem do mundo tenha rompido definitivamente a vitalidade da tradição cristã, como às vêzes afirmam historiadores da Renascença e do Iluminismo.

Basta lembrar a crença nos direitos fundamentais do homem, considerados, por princípio, irrenunciáveis, imprescritiveis e anteriores ao Estado, o que pressupunha, em última análise, a idéia de ser o homem, não obstante a sua queda, a imagem de Deus. Esta crença tinha recebido a sua expressão política-clássica já muito tempo antes da codificação dos direitos fundamentais do homem, por Locke, no seu tratado sôbre o govêrno, que representa o pensamento político inglês. Os direitos fundamentais de liberdade, vida e propriedade são aqui entendidos como mútua dependência. $O$ homem não se pode locomover em liberdade, se, eventualmente, lhe pode ser tirada a vida. Por sua vez a garantia da vida tem como conseqüência que a vida, para ser digna de ser vivida, o deva ser com liberdade. Mas sendo protegidas vida e liberdade, também a propriedade tem de participar dessa proteção, cuja existência pressupõe êsses direitos. Nas declarações dos direitos fundamentais do homem, mais tarde, êstes direitos foram desenvolvidos nas mais variadas direções, formulados e canonizados nas formas tradicionais.

Esta crença nos direitos anteriores ao Estado, direitos do indivíduo à vida e à liberdade, a qual, em certas circunstâncias, legítima o indivíduo a afastar um eventual regime despótico e colocar no lugar do mesmo um regime constitucional, é, em última análise, sustentada por uma crença, comum ao Humanismo, ao Racionalismo, ao Iluminismo e ao Direito Natural, ou seja pela crença no 
homem, na razão, na natureza comum a todos os homens, crença essa que transcende qualquer pensamento coletivista, quer êste se oriente no sentido do Estado, ou da Nação, ou do Povo. Mas, sendo o homem um ente racional, êle pode exigir que, por princípio, suas opiniões sejam respeitadas, também por aquêle que pensa de modo diferente, assim como êle deve respeitar as opiniões dos dissenters. Pois no respeito que demonstro ao outro, ainda que se distancie da sua opinião, manifesta-se simplesmente o respeito à razão (Ratio), a qual se serve de outro homem sòmente como de um especial recipiente, para se revelar. Daí a crença na fôrça criadora da discussão, do argumento e do contra-argumento, da crítica positiva e do compromisso construtivo. A idéia básica de uma discussão consiste em que os contendores, deixando-se dirigir pela razão, são acessiveis a considerações razoáveis e, portanto, se deixam convencer por argumentos razoáveis. Desta forma, a discussão conduz a um compromisso construtivo o qual contém a solução mais razoável nas circunstâncias reinantes. Foi essa crença no mútuo debate arrazoado que proporcionou ao parlamentarismo o seu princípio histórico-cultural e, outrora, ao parlamentarismo inglês a sua grandeza.

Segue-se lògicamente que um tal parlamento faz participar das suas discussões, por assim dizer, todo o povo. Argumento e contra-argumento devem crescer de pêso, pela luz da publicidade. Pela publicidade deve ser transmitida ao povo a crença de realizar-se uma discussão verdadeiramente criadora e construtiva. Uma discussão arrazoada à luz da publicidade vem garantir, assim, a progressiva realização do reino da razão.

Igualmente acreditava-se poder assegurar do melhor modo a exata solução total deixando agir em liberdade o indivíduo racional. O princípio econômico do laisser faire, laisser aller, considerando o próprio interêsse a única fôrça motriz e norma reguladora, é sòmente uma, ainda que importantíssima, expressão dessa disposição 
geral, bem como da crença de que uma economia fundada no próprio interêsse é a melhor garantia do seu bom funcionamento.

Polìticamente encontrou êste pensamento democráticoliberal a sua expressão naquilo que, geralmente, se chama a democracia representativa parlamentar. Numa tal democracia os deputados não devem sofrer perante o povo uma capitis diminutio por influência decisiva de grupos de eleitores ou de outras organizações, sôbre suas decisões. A liberdade da decisão pertence, diretamente, à essência do sistema representativo parlamentar. Sòmente em conseqüência disto encontra-se, desde a Revolução Francesa até a Constituição de Bonn, em tôdas as constituições escritas, o axioma fundamental de que os deputados não estão sujeitos a ordens e instruções. Êste axioma, ventilado na literatura das mais variadas direções, tem como base a exata idéia de que um deputado privado do seu poder da decisão, dependente da vontade de um mandante, seria degradado a um mensageiro e, con 1 isto, despojado do seu próprio valor e do seu caráter representativo.

Por esta razão, o assim chamado "mandato imperativo", sem distinção da forma na qual e da pessoa por quem (eleitores, partidos) fôr usado, contradiz as idéias do sistema representativo parlamentar-liberal. Burke, certa vez, o declarou no seu famoso discurso aos eleitores de Bristol: Authoritative Instructions, Mandates issued. . are things utterly unknown to the laws of this land, and which arise from a fundamental mistake ;of the whole order and tenor of our constitution. Porisso, também não é possível, como se tentou várias vêzes, reconciliar o "mandato imperativo", em qualquer forma, com o sistema representativo parlamentar. $O$ conceito da representação pertence aos conceitos políticos essenciais. Representação e "mandato imperativo" excluem-se mùtuamente.

Daí vem que tôdas as constituições representativas liberais, possuam caráter democrático ou não, neguem a 
obrigação política de justificação e a responsabilidade dos deputados para com eleitores e outras organizações políticas. O deputado deve orientar suas decisões pela sua consciência que, exclusivamente, garante a legitimidade das decisões políticas a serem tomadas pelos representantes. Faltando, desta forma, uma concreta responsabilidade política, é, ao mesmo tempo, excluido o recall em qualquer de seus possíveis aspectos, dentro do parlamentarismo representativo.

Segundo o estipulado em tôdas as constituições que reconhecem o sistema representativo, desde a Revolução Francesa, um deputado não pode ser representante de um determinado grupo de eleitores ou distrito; êle tem de representar a nação inteira. Blackstone, no seu famoso comentário no fim do século XVIII, assim circunscrevia a tarefa dum member of parliament: Every member, although chosen by one particular district, when elected and returned, serves for the whole realm. Foi esta concepção que mais tarde, sempre e sempre repetida, se apresentou na teoria do Estado do século XIX. Ela baseia-se na idéia de que o parlamentarismo representativo pressupõe a existência do povo como unidade política. Segundo esta concepção, cada representante tem de possuir as qualidades de um patrão e não de um empregado. Tem de ser o possuidor de um determinado valor próprio pessoal. Tem de fazer jus a uma autoridade e dignidade próprias. $O$ tradicional direito da imunidade parlamentar, que ocupa nas constituições escritas um espaço tão amplo, recebe, sòmente sob êste aspecto, o seu verdadeiro sentido e a sua justificação.

Dêste ponto de vista teórico, torna-se, também, compreensível a razão não sòmente por que não se contava com a possibilidade da formação de partidos políticos no tempo da revolução americana e da francesa, mas ainda porque no século XIX, no continente, houve oposição ao reconhecimento dos partidos políticos. Tinha-se, instintivamente, o exato pressentimento de que a admissão de 
partidos e frações políticas exporia a um gravíssimo risco a liberdade dos deputados, e que uma legislação dos partidos poria em perigo os fundamentos do sistema representativo parlamentar. E quando, no decorrer do tempo, se evidenciou a impossibilidade de continuar esta politica ostensivamente hostil ao partido, tentou-se retardar, o mais possivel, o desenvolvimento dos partidos políticos. Isto explica porque até o século $\mathrm{XX}$ não foi feita menção alguma do partido, nem em constituições, nem em leis ordinárias, nem em regulamentos. Preferia-se caraterizar os partidos com "grupos de eleitores" ou "associações de eleitores" para deixá-los aparecer como mais inócuos. Nesta situação também não é estranhável que proeminentes professôres alemães do direito constitucional, em suas exposições sistemáticas, ou não fizessem menção alguma dos partidos políticos - pense-se, por exemplo, em Paul Laband - ou declarassem expressamente - como, por exemplo, Georg Jellinek - que ao conceito do partido não cabe papel algum na ordem estatal.

Também de outra forma encontrou o pensamento democrático europeu-ocidental sua expressão no terreno político-organizador. Procurou-se garantir o mais possível, por meio de uma série de entraves, a vida, a liberdade e a propriedade contra intervenções abusivas. Daí o sistema de separação dos poderes, que, na determinante formação da vontade do Estado, antes de tudo na legislação e no orçamento, colocou uma pluralidade de instâncias de mútuo contrôle, uma em frente da outra, e corroborou isto ainda - especialmente na monarquia constitucional - pelo sistema de duas câmaras, que, igualmente, atua moderando e equilibrando os órgãos legislativos.

Pela mesma razão, a lei, num Estado constitucional e de direito, tem de conter uma norma teòricamente comensurável e universalmente obrigatória, da qual não devem ser arbitràriamente concedidas excessões em favor ou prejuizo de determinadas pessoas. No mesmo sentido, ou scja, para garantia da vida, liberdade e propriedade, exer- 
cem sua ação também as cautelas específicas do Estado de direito. Pertencem a estas a independência da jurisdição, que sujeita o juiz exclusivamente à lei, o princípio da legalidade da administração, princípio êsse que Thoma, em 1910, ainda qualificou de fundamento da idéia do Estado de direito e que exclui qualquer possibilidade de intervenção arbitrária do Executivo na esfera da liberdade individual, bem como a existência da jurisdição administrativa, independente, pela qual a atividade legislativa das autoridades administrativas é controlado quanto à sua legalidade e legitimidade. Todos êstes princípios pressupõem a congruência da lei formal e do direito material. No século XIX esta firme confiança na relação orgânica da forma com o conteúdo não foi abalada, graças à estabilidade das condições políticas e econômicas e à existência do mencionado sistema político de contrôle.

As experiências, porém, dos últimos tempos nos Estados totalitários mostraram que a identidade de lei e direito, se pode tornar problemática. Legalidade e legitimidade não devem ser identificadas. Uma norma de cunho geral nem sempre é justa. Para corrigir essa tensão potencial entre legalidade e legitimidade foi atribuída, progressivamente, independência ao Terceiro Poder e introduzida em alguns países uma justiça constitucional. A tarefa de uma tal justiça constitucional consiste em dar solução, nos moldes da jurisdição, em favor do direito, à antinomia existente entre o direito e a política, o normativo e o existencial, e com isto garantir, tanto quanto possível, a equivalência entre legalidade e legitimidade.

Esta ordem estabelecida para a proteção da liberdade pressupõe um conceito de liberdade que não deve ser identificado com arbítrio e irresponsabilidade individuais. Pelo contrário, a liberdade política, assim como a liberdade da ciência, a liberdade da religião, a liberdade do juiz, pressupõe, como produto complementar, um dever, ou seja, um compromisso entre liberdade e lei, entre o sujeito e o objeto. Neste sentido também Ruggiero define 
ser politicamente livre como "ser o seu próprio dono", isto é, ser independente dos outros no sentido de qualquer dependência forçosa, substituindo-se esta por aquela que a consciência do dever, para consigo mesmo e os outros, espontâneamente exige. Nêste sentido, liberdade significa "a transferência da fonte da autoridade e lei para o íntimo do próprio espírito". Mas por causa dêste vínculo a liberdade ainda não é staatsfromm ou autoritäte-glaubig. Pois o reconhecimento de um próprio domínio político é sòmente a forçosa suposição que permite à liberdade seu funcionamento político. Esta intensa idéia conservadora do Estado, que é o elixir de vida da democracia liberal, chamou-se, não sem razão, "o extra-estatal compensador", no qual a polaridade geral do social encontra 'sua expressão.

O pensamento democrático-liberal, que caracterizamos até agora, visto de perto é mais liberal que democrático. Liberalismo e democracia não se identificam, pois em última análise se orientam por diferentes valores básicos políticos. Isto demonstra-se já pelo fato de que o liberalismo, no século XIX, se pôde aliar também à Monarquia. Liberalismo e democratismo podem conjugar-se mas também podem estar em oposição mútua. A história fornece muitas provas de adversários potenciais se aliarem por razões táticas, contra um comum adversário. Tais alianças podem disfarçar, temporàriamente, as tensões existentes, até que o comum adversário seja despojado do seu poder.

Sob êste ponto de vista, é um bom exemplo a história do direito do voto, nos últimos cem anos, porque ela é sòmente a expressão de um conflito entre liberalismo e democratismo, disfarçado pela luta comum contra a Monarquia. Esta tensão também torna, ao mesmo tempo, compreensivel a razão porque no século XIX não sòmente 
os conservadores, mas também os liberais opuzeram uma apaixonada resistência à extensão mais ampla do direito do voto. Não se pode estranhar que êsse latentè conflito entre liberalismo e democratismo tivesse terminado no decurso do último século, em todos os países europeus, com a vitória das fôrças radical-democráticas, mais fortes.

Que o democratismo também pode assumir um caráter anti-liberal está manifesto já em Rousseau, que aboliu, teòricamente, a existência pessoal do homem e pôs, simplesmente, o indivíduo à disposição da comunidade. Já aqui o homem por si não mais é sujeito, mas sim objeto - o instrumento simplesmente equiparado da volonté générale. É certo que a democracia liberal da Revolução Francesa, proclamando os Direitos do Homem, não aceitou essa forma do democratismo. Mas a possibilidade de uma tal democracia não nos dispensa do dever de analisar ainda, mais de perto, o pensamento democrático, independentemente do seu teor liberal.

Cada democracia pressupõe que o povo é soberano, isto é, que todo poder provém do povo, e que o povo é sujeito e possuidor do poder constituinte. O povo, como fonte de poder político de decidir, tem de tomar, as supremas decisões políticas e as determinantes decisões judiciárias diretamente ou através de instâncias representativas, devidamente legitimadas pelo povo e limitadas na sua competência. O povo é soberano quando é a última, suprema, universal instância decisória numa comunidade política.

Contudo, que devemos entender por "povo"? Lincoln definiu a democracia como a government of the people, for the people, by the people. Isto quer dizer: à medida que mais homens participam na formação da vontade do do povo, à medida que aumenta a participação dos cidadãos ativos na formação do common will, torna-se mais democrático um regime. Disto resulta, ao mesmo tempo que a igualdade é o próprio conceito substancial da demo- 
cracia, porque é por ela que, em substância, o govêrno do povo é realizado.

Contudo, que devemos entender por "igualdade", numa democracia? Sem dúvida, êste conceito quanto ao seu conteúdo não pode ser definido com precisão aproximativa através de um critério formal, especialmente numérico. É certo que também isto foi tentado bastando lembrar Aristoteles, Bryce e Kelsen. Mas tôdas essas tentativas não puderam convencer. De fato, o conceito da igualdade não se deixa definir a priori. Ao contrário, êle é mutável quanto ao conteúdo, e depende, na sua forma concreta, das condições de tempo e lugar, sociais e políticas. Sòmente através desta relação o conceito da democracia é tirado da sua abstração e torna-se um conceito concreto històricamente determinado, e podemos, à medida do seu teor político-concreto que se liga à igualdade, distinguir várias formas e tipos da democracia.

Na democracia moderna, determina-se hoje o conceito da igualdade por um critério de igualitarismo radical em lugar da igualdade diferenciada, do século XIX. No século XIX a igualdade ainda era entendida mais no sentido daquela igualdade aristotélica segundo a qual cada um, por princípio, deve ser medido segundo o medidor que lhe corresponde. Esta igualdade, a assim chamada proporcional, quer, por princípio, tratar os homens de modo desigual, correspondente às suas disposições, seu caráter, seu intelecto. Segundo esta concepção, seria gravemente ferida a igualdade se as diferenças existentes entre os homens fôssem ignoradas e os homens fôssem tratados com igualdade absoluta. É esta igualdade proporcional ou relativa que transmitiu ao liberalismo o seu caráter próprio, ao mesmo tempo democrático e aristotélico. E partindo desta posição teórica foi que, no século XIX - ainda que numa forma rudimentar e primitiva - os homens foram tratados de modo diferente, na esfera política, e certas camadas da população foram excluídas dos direitos políticos ou admitidas sòmente com limitações, na forma- 
ção da vontade política. Sòmente desta forma pode ser explicado, por exemplo, o direito de voto qualificado, pelo qual certos grupos da população receberam um voto suplementar, porque tinham alcançado um mais alto grau de instrução ou uma determinada idade.

Tudo isto hoje não é mais possível. Ao contrário, as diferenças que de fato existem entre os homens, as quais, no século XIX, foram consideradas essenciais, parecem hoje insignificantes diante das qualidades comuns aos homens. Hoje é atribuído aos homens, por princípio, um valor absolutamente igual, salvo a desigualdade do seu valor social e as diferenças existentes entre êles, da família, da classe, da instrução, da raça, da nacionalidade. Assim, também, o conceito moderno de igualdade exclui qualquer restrição social, sobretudo se determinada pela classe, a que poderia conduzir a uma diferenciação dos cidadãos ativos. De fato, a inclusão de considerações de classe, fortuna, instrução e semelhantes, na formação da vontade comum, poria em perigo, hoje, a democracia. Assim pode-se dizer que a igualdade que imprime ao conceito da democracia moderna o seu cunho decisivo não mais é a igualdade proporcional, pela qual os cidadãos, segundo o lema de suum cuique, são tratados de modo diferente, mas sim a igualdade matemática aritmética.

Êste progressivo processo de tornar formal e radical a igualdade ainda hoje não está concluído. Isto vale até para a esfera política, quando pensamos, por exemplo, na introdução do sufrágio feminino em número sempre crescente de países no decurso das últimas décadas, ou na contínua igualização dos distritos eleitorais nos países onde se conservou o sistema majoritário, ou ainda no progressivo aperfeiçoamento da representação proporcional, que deve dar a cada cidadão a certeza de que o seu voto não sòmente é avaliado, no ato da deposição, com absoluta igualdade, mas também produz, na contagem, um efeito útil. O processo igualitário-radical de democratização, uma vez iniciado, continua sua ação devido a uma 
dinâmica inerente. Sempre novos domínios, ultrapassando o terreno político, são submetidos a êste processo de progressivo igualitarismo. A êste respeito, cumpre lembrar as alterações profundas, quase revolucionárias, nos terrenos social, econômico e cultural, realizadas na maioria dos países europeus, nos últimos anos, e já tendo conduzido, por meio de intervenção estatal e uma ampla orientação da economia pelo Estado, num certo número de países, a uma homogeneidade, que nos autoriza a falar não sòmente de uma democracia politicamente formal, mas também, e numa proporção não insignificante, de uma democracia social e econômica, compreendendo cỉdadãos ativos (na órbita política), mas também cidadãos na órbita econônica.

A progressiva recepção, nas constituições modernas, de direitos fundamentais sociais e princípios estatais-sociais, como por exemplo, os do Estado social de direito na Bonner Grundgesetz (Lei Fundamental de Bonn), significa que concepções igualitário-radicais foram transferidas, em proporções crescentes, da esfera política para a da vida social. Direitos fundamentais sociais não são, realmente, direitos fundamentais autênticos, mas - porque se baseiam no princípio da igualdade democrática - direitos de status. São direitos que, nos moldes da justiça, a ser em tempo determinada, são "concedidos" à medida das leis, pelo Estado, mas não "garantidos". Existe, portanto, uma tensão entre os autênticos direitos fundamentais liberais e os assim chamados direitos fundamentais sociais. Esta tensão é necessária e, em última análise, também irremediável. Ela encontra sua expressão no fato de que os direitos fundamentais sociais, em contraste com os direitos fundamentais liberais, produzem deveres concretos e limitam as liberdades concedidas pelos direitos fundamentais liberais. Ela também explica porque os assim chamados direitos fundamentais sociais, em contraste com os direitos fundamentais liberais, teòricamente, podem ser reälizados também num Estado não liberal. Afinal resulta da parti- 
cularidade dêstes direitos fundamentais sociais o fato de que êles ainda necessitam, segundo o caso, de uma concretização de conteúdo mais precisa e de uma atualização. Êles contêm compromissos do legislador e não do juiz. A êste obrigam os direitos fundamentais sociais sòmente na medida segundo a qual os princípios jurídicos se tornarem judiciáveis através de uma suplementar precisão do conteúdo.

Êste progressivo igualitarismo conduziu, hoje, no domínio do político e social, a uma ampla democratização e des-liberalização. Sem dúvida, também no domínio da esfera especificamente democrática, a liberdade é imprescindível na medida em que é necessária para garantir a igualdade democrática. Portanto, é a exigência de "eleições livres" uma exigência verdadeiramente democrática. Por outro lado, do ponto de vista democrático-liberal, a igualdade é abrangida pela liberdade. A liberdade é limitada sòmente tanto quanto isto é necessário para garantir, na mesma medida, aos outros indivíduos a sua liberdade. Neste sentido, uma distinção individual, na base da liberdade, pressupõe uma possibilidade legal de comparação.

Sòmente assim pode-se também compreender por que a igualdade representou, na formação democrática da vontade, um papel tão importante, e a democracia pôde ser descrita como uma série de identidades. Realmente, na democracia plebiscitária, em contraste com a democracia representativa, a vontade comum forma-se pela identificação da vontade da maioria dos cidadãos com a vontade da totalidade.

Também o princípio de maioria é democrático, porque garante o maior grau possível de igualdade política e com isto a maior congruência possivel da vontade individual com o conteúdo da vontade da totalidade. No passado costumavam as minorias renunciar à sua oposição e com isto possibilitar uma unânime tomada de resolução do povo que se sente e vota como unidade homogênea. Hoje, 
ao contrário, é identificada primeiro a vontade da maioria da população com a da coletividade dos cidadãos ativos, depois a vontade da coletividade dos cidadãos ativos com a comunidade total. Certamente, o princípio majoritário tem também um componente liberal. Transmite a fé na fôrça da decisão da maioria, para promover a verdade. Esta fé na racionalidade e certeza da decisão da maioria pertence ao pensamento do iluminismo, do liberalismo e porisso, politicamente, também do parlamentarismo representativo. Não foi por acaso que a ampla des-liberalização política, hoje, também conduziu à uma crescente desilusão dessa justificação do princípio majoritário.

\section{III}

A progressiva democratização igualitário-radical conduziu, nos países modernos, a um grande crescimento do poderio dos partidos políticos. São êles que organizam os milhões de cidadãos chegados à maioridade política e os mobilizam para a ação. Só êles reunem os eleitores em grupos capazes de ação política e apresentam-se, assim, como o microfone do qual se serve o povo, chegado à maioridade, para articular seu pronunciamento. Pode-se mesmo dizer que a moderna democracia, na maioria dos países ocidentais, assumiu, mais ou menos, o caráter de uma democracia representativa de partidos, isto é, de uma democracia que se baseia nos partidos como unidades de ação política. Sem a intercessão dos mesmos, o povo, hoje, simplesmente não estaria na situação de exercer uma influência política sôbre os atos do Estado e, dessa maneira, atuar concretamente na esfera política.

Trata-se, nesta democracia representativa de partidos, em verdade, de uma forma da democracia que na sua estrutura fundamental, é diferente da tradicional democracia parlamentar representativa-liberal. Isto é de má- 
xima importância a respeito quer da teoria, quer do direito constitucional.

1. ${ }^{\circ}$ A diferença teórico-constitucional fundamental entre o moderno Estado democrático representativo de partidos e a tradicional democracia representativa-parlamentar origina-se, decididamente, do fato de não ser o Estado, em regime de partidos, na sua essência e forma, outra coisa senão um aspecto racionalizado da democracia plebiscitária.

$2 .^{\circ}$ Disto se segue que a vontade do povo ou a vontade comum é formada, na atual democracia representativa, pelos partidos. Não o princípio político da representação, mas sim o princípio que na democracia plebiscitária conduz à formação da vontade comum, conduz também, na democracia representativa de partidos, à formação da vontade da totalidade do povo. Como na democracia plebiscitária a vontade da maioria dos cidadãos ativos é identificada com a atual vontade da totalidade, assim numa democracia representativa de partidos em funcionamento é identificada à vontade da atual maioria partidária no govêrno e no parlamento com a vontade da totalidade.

3..$^{\circ}$ Em conseqüência da evolução caracterizada, da democracia representativa-parlamentar para democracia representativa de partidos das massas, o parlamento perde aos poucos o seu anterior caráter primitivo e se torna, cada vez mais, um lugar no qual se encontram mandatários de partidos para registrar decisões já tomadas fora do parlamento, por exemplo, em comissões, ou reuniões de partidos. Além disto, perde a discussão o seu anterior caráter criador e construtivo - como êste fato, muitas vêzes, foi mais minuciosamente descrito na literatura. Os discursos que são proferidos no parlamento vão deixando de ter a finalidade de convencer os deputados de opinião diferente, e se dirigem diretamente aos cidadãos ativos, que devem ser impressionados na sua opinião, pelos argu- 
mentos proferidos, e influenciados nas suas futuras decisões políticas. A publicidade, que outrora proporcionou às discussões parlamentares seu especial brilho, assume um caráter plebiscitário suplementar, adaptado ao específico processo de integração da democracia representativa de partidos. Assim é que nos Estados ocidentais em regime de partidos o centro da gravidade política se desloca do parlamento, de um lado para os cidadãos ativos, os partidos políticos que se organizam, e de outro para o govêrno.

4. ${ }^{\circ}$ Muitas vêzes foi observado, na praxe como na literatura, que essa modificação na posição do parlamento também modificou, decisivamente, a posição do próprio deputado no parlamento. Do ponto de vista de uma democracia representativa de partidos planejada lògicamente, os partidos políticos, de fato, podem reclamar o direito de se impor perante os seus membros. Numa tal democracia o deputado aparece como teòricamente sujeito a uma vontade alheia, e não mais pode ser considerado um representante que livremente, sob responsabilidade pessoal, toma decisões políticas. Nesta democracia falta, no fundo, ao deputado a última legitimidade para seguir em assuntos de importância política, uma linha diferente da dos partidos e facções. - Em última análise torna-se assim o deputado, no moderno Estado representativo de partidos, um membro intermediário técnico-organizador, o qual parece indispensável sòmente na medida da sua missão de colaborador ou, dentro do partido, na formação da vontade do partido, ou, do ponto de vista da comunidade, na formação da vontade da maioria dos partidos.

Assim se explica que o deputado numa democracia representativa de partidos esteja sujeito, hoje, a uma multiplicidade de compromissos partidários, os quais, decisivamente, influem nos seus discursos e nas votações. $O$ "mandato imperativo" e a disciplina da facção, que leva os membros de uma facção a obedecer às decisões toma- 
das pelo partido ou pela facção, encontram aqui o seu lugar e a sua justificação orgânica.

A êste respeito não importa, do ponto de vista do Estado representativo de partidos, o motivo que leva o deputado a equiparar-se. Pode ser que o deputado tenha sido persuadido e, portanto, julgue a decisão do partido ou da facção como correspondente ao interêsse da comunidade. Pode ser que êle, no intimo, se considere tão comprometido para com o partido que se sinta na obrigação de sacrificar, no interêsse do mesmo, a sua opinião própria julgada como melhor. Possivelmente êle faz êste sacrifício sòmente para evitar, dêste modo, eventuais desvantagens as quais, caso contrário, talvez o ameaçassem do lado do partido.

$5 .^{\circ} \quad$ Outra conseqüência está no fato de ser o deputado responsabilizado, pelo partido, por um seu eventual comportamento contrário ao partido. A questão, outrora muitas vêzes atual e também discutida na literatura, de saber se, é, em caso afirmativo, até que ponto, os eleitores podem responsabilizar os seus deputados pela falta do cumprimento dos compromissos assumidos, perdeu na moderna democracia representativa de partidos seu significado na medida em que os partidos tomaram o lugar dos eleitores. Como o guarda da vontade do povo manifestada através dos partidos, o partido pode até expulsar da sua organização o deputado, um fato que, na maioria dos casos, pràticamente significa o fim da carreira política do mesmo. A última conseqüência de um Estado democrático em regime de partidos, planejado, lògicamente, está no fato de uma expulsão do partido (assim como a mudança de um partido para um outro) resultar na perda do mandato parlamentar. O recall é uma instituição que está em contraste com o democratismo parlamentar-representativo e, conforme as normas da sua estrutura, intimamente ligado ao moderno Estado de partidos nas democracias de massas. 
6. Nestas circunstâncias, não é de admirar que também as atuais eleições parlamentares comecem a mudar fundamentalmente de caráter. Vistas à luz do dia, estas, hoje, muitas vêzes não mais são autênticas eleições. Ao contrário, elas têm, cada vez mais, a tendência de se tornar um ato puramente plebiscitário no qual os cidadãos ativos, agrupados pelos partidos, manifestam sua vontade política coletiva em favor dos candidatos indicados pelos partidos e dos programas partidários dos mesmos. A esta mudança não obedece a Lei Fundamental de Bonn (Bonner Grundgesetz), a qual, como a maioria das outras constituições, em forma tradicional, declara que a vontade do povo se manifesta em "eleições" e "votações". Apesar da tendência anti-plebiscitária da Lei Fundamental de Bonn, as eleições tornaram-se uma espécie de plebiscito. Por esta razão também não existe na atual democracia representativa de partidos nem uma orgânica necessidade, nem uma especial justificação de instituições plebiscitárias suplementares.

7. Quanto mais concretas e precisas sejam as decisões políticas plebiscitárias dos cidadãos ativos agrupados em partidos, tanto melhor funcionará um Estado democrático-representativo de partidos. Na Inglaterra tiveram as eleições, em parte já no século XIX e no começo do século $\mathrm{XX}$, um caráter plebiscitário concreto nêsse sentido.

Nas democracias européias ocidentais do continente, que não conhecem o sistema bipartidário, a função plebiscitária-concreta das eleições, naturalmente, não se pode manifestar de forma tão precisa. Poìs num Estado pluripartidário não se pode como num Estado bi-partidário tornar um definite issue objeto de uma "eleição", embora a existência de uma pluralidade de partidos não exclua necessàriamente interrogações plebiscitárias nas eleições. Também estão crescendo nos Estados pluripartidários as tendências favoráveis à introdução de uma formação de blocos, disfarçada e às vêzes aberta, criando desta ma- 
neira, as condições para que, nêsses Estados a orientação básica do govêrno seja fixada por meio de eleições, para uma série de anos. Onde, porém, o caráter pluripartidário de uma democracia hoje ainda não permite decisões plebiscitárias imediatas através das eleições, estas - em todo o caso à medida em que os cidadãos ativos são organizados nos partidos ou tàcitamente participam dos mesmos — exercem funçõ̃es registradoras-estatísticas, que, na sua tendência teórica, têm estreitissima conexão com a democracia plebiscitária e não com a representativa.

À medida que se pode hoje falar de um caráter plebiscitário-concreto das eleições num moderno Estado em regime de partidos, não prescinde de razão submeter assuntos de importância fundamental, que tangem à existência da nação, à decisão da coletividade dos cidadãos ativos numa democracia em regime de partidos, que não está sobrecarregada por elementos estruturais sobreviventes da democracia representativa. Neste sentido existe, por exemplo, na Inglaterra, como convenção, a regra de que, por princípio, não se deve efetuar uma mudança radical de política, sem "mandato" do povo. Esta concepção baseia-se na idéia de que, numa democracia em regime de partidos, os partidos se apresentam como executores da vontade da coletividade dos cidadãos ativos, e que govêrno e parlamento estão autorizados à ação política sòmente nia medida de um mandato circunscrito pelo programa partidário, mandato êsse que lhes foi conferido nas eleições.

Sob êste aspecto principal, na Inglaterra, não raras vêzes, é qualificado de inconstitucional o procedimento do govêrno e da maioria parlamentar, no caso de serem tomadas importantes decisões políticas de significação fundamental que são incompatíveis com o mandato conferido. Também na Alemanha, por ocasião da discussão sôbre a constitucionalidade do Wehrbeitrag, bem como do Deutschlandvertrag, foi por parte da oposição alegado que o eleitorado teria de ser novamente consultado, porque o 
Deutsche Bundestag na sua composição atual não mais possuiria a legitimação para decidir estas questões.

$8 .^{\circ}$ À função modificada que as eleições geralmente exercem, hoje, na democracia em regime de partidos, corresponde o fato de que o deputado é eleito ao parlamento não mais devido à sua personalidade e suas qualificações particulares, como na democracia representativa parlamentar, mas sim como membro de um determinado partido. Hoje, a personalidade política não mais é aquela personalidade representativa livre, apresentando-se aos eleitores, a qual no conceito do século XIX representava uma parte da aristocracia intelectual, mas, no fundo, o "expoente do partido político", como já observou, uma vez, o antigo ministro de culto Grimme.

Aliás, não é certo afirmar que os cidadãos ativos não organizados em partidos se orientariam em sentido liberal tradicional, se, por acaso, através de fundamental modificação do sistema eleitoral, os partidos não mais fôssem os exclusivos fatôres da luta eleitoral. Até agora faltam ainda pesquisas seguras sôbre a reação política dessa parte dos cidadãos ativos. Pesquisas que foram feitas, principalmente na Inglaterra, sôbre esta questão, aproximam-se da conclusão de que a grande maioria do Treibholz não deve ser considerada como tal, porque também os cidadãos ativos não agrupados em partidos, na sua maioria, se sentem, mais ou menos, comprometidos para com os partidos. Êles são adeptos dos partidos, ainda que não se tenham comprometido na qualidade de membros. $O$ verdadeiro floating vote representa, portanto, uma percentagem dos cidadãos ativos muito menor da que se supõe geralmente.

O fato de ser êste Treibholz, no moderno Estado democrático em regime de partidos, — aliás em contraste com a democracia representativa-parlamentar - avaliada negativamente na política corresponde sòmente à mudança na estrutura da democracia. Pois no Estado em regime de 
partidos os milhões de cidadãos ativos que limitam sua atividade política sòmente a ir, cada quatro ou cinco anos, às urnas para satisfazerem os seus deveres cívicos, apresentam-se como os aproveitadores que vivem do trabalho dos outros, os quais dedicam sua vida ao trabalho político nos partidos, sacrificando, não raras vêzes, tempo, saúde e dinheiro. Nesta situação não é estranhável que os grupos que alicerçam, através dos partidos, o Estado façam valer, hoje, suas pretensões e queiram ver protegidos os seus direitos adquiridos da mesma forma como foi o caso, quando outras fôrças alicerçaram o Estado.

9. Reformas eleitorais no sentido tradicional, produtos do espírito do século XIX, no sentido do parlamentarismo representativo-liberal, não mais são oportunas. No fundo, pertencem elas ainda, segundo tôda a sua disposição, a uma época passada. Para a democracia em regime de partidos, que obedece a leis de estrutura próprias, a forma do processo eleitoral não tem mais significação decisiva alguma.

\section{IV}

A tese enunciada nêste artigo visa a mostrar que, na moderna democracia em regime de partidos, há um novo tipo de estrutura da democracia. A nossa atual crise caracteriza-se, em geral, pelo fato de procurarmos enfrentar uma realidade, alterada em todos os aspectos, ainda com as idéias, categorias, conceitos procedentes de uma época passada.

Para evitar, de antemão, mal-entendidos, fique bem claro que não afirmo que não devem ser respeitados os elementos sobreviventes da estrutura representativa, que ainda se acham, comprovadamente, na maioria das constituições escritas. Mas para as necessárias reformas serem bem encaminhadas, os problemas tem de ser encarados 
adequadamente. $\mathrm{E}$ isto só me parece possivel desde que reconheçamos o moderno Estado democrático representativo de partidos, tal como existe, e procuremos enquadrá-lo, de forma adequada, na teoria e no sistema constitucionais. Na medida em que modificações estruturais se torraram realidade política e, além disto, também realidade constitucional, a ciência política deve, antes de tudo, levá-las em conta, compreendendo-as e interpretando-as.

Quem, portanto, queira satisfazer, hoje, às necessidades da democracia de partidos, deve tentar fazer tudo para tornar possível o funcionamento dêste Estado em regime de partidos; ou seja, providenciar para que os partidos, como instrumentos imprescindíveis da nova democracia, não se tornem, ao mesmo tempo, os seus destruidores potenciais. Para alcançar êste fim, e para não deixar os partidos se apresentarem como organizações ditatoriais com regime centralista e autoritário, antes de tudo os próprios cidadãos ativos têm de ser mobilizados - màs não pelos meios tradicionais do liberalismo representativo parlamentar e de uma reforma eleitoral no sentido liberal. Cumpre levar avante uma democratização dos próprios partidos, enquadrando a êstes de forma democrática no Estado.

Uma tal democratização exige, antes de tudo, que a formação da vontade dentro dos partidos se efetue "de baixo para cima", isto é, que os atuais líderes de partidos sejam legitimados, na sua autoridade, através do princípio majoritário. O problema, portanto, consiste em fazer tudo para evitar que o mecanismo e a burocracia partidários oponham, por meio da moderna técnica de organização, a sua vontade à vontade dos cidadãos partidários e a imponham a esta e, afinal, ao povo inteiro. Isto não significa que os cidadãos ativos organizados em partidos tenham de tomar, êles próprios, tôdas as relevantes decisões do partido.

Uma tal democratização do partido, porém, exige não sòmente uma estrutura democrática das organizações par- 
tidárias, mas, além disso, que a posição jurídica do próprio partido seja organizada democràticamente. Para isto é, antes de tudo, imprescindível que os cidadãos partidários, em todos os pormenores, sejam tratados, pelos partidos, juridicamente de forma igual, que tenham o igual - e sobretudo secreto - direito eleitoral e do voto, e que possam fazer, sem restrição, uso do direito da liberdade da opinião, nas reuniões, especialmente também nos congressos do partido.

A democratização dos partidos exige, outrossim, a democratização da escolha dos candidatos aos parlamentos. Pois é sòmente dêste modo que se torna possível quebrar a política secreta da burocracia partidária e suprema hierarquia partidária. As primary elections nos Estados Unidos, servem, como é sabido, para êste fim, sem complemento alcançá-lo na prática, visto que não conseguem quebrar decisivamente o poderio da burocracia partidária.

Outrossim, a democratização dos partidos requer que os mesmos sejam protegidos contra influências antidemocráticas. À democratização do Estado em regime de partidos corresponde, finalmente, a exigência de serem colocados, à disposição dos partidos, veículos de publicidade.

De uma tal democratização depende, a meu ver, o futuro do moderno Estado democrático em regime de partidos, e, com isto, o destino da democracia. 